DOI: https://doi.org/10.32839/2304-5809/2019-8-72-43

UDC 781.7

Pyzhianova Nataliia, Kutsenko Serhii, Opatskyi Ihor

Pavlo Tychyna Uman State Pedagogical University

\title{
RESEARCH OF THE INFLUENCE OF CHURCH EDUCATIONAL INSTITUTIONS ON THE PROCESS OF FORMING THE SPECIFICITY OF SONG PERFORMANCE IN CENTRAL UKRAINE
}

Summary. The article reveals the role of church cells in the process of spreading music education in Central Ukraine. It is noted that the music education of the second half of the XIX - beginning of the XX centuries in Cherkasy region had some signs of professional education. The activity of church and church-parochial choral groups of Cherkasy region is analyzed. It was found that music education, in particular, choral performance, was distributed mainly through spiritual schools, where ensembles and choral groups were formed. It is noted that the functioning of an extensive network of church educational centers contributed to the development of musical literacy among the population, created the preconditions for creative self-realization, increased the overall cultural level. The practice of individual choral groups functioning formed on the basis of church educational establishments is analyzed. The interaction of church and secular, folk singing traditions contributed to the formation of a new manner. It is stated that the repertoire of church choirs was supplemented with spiritual folk songs, works of the calendar-ritual cycle. It is noted that the touring activity of choral groups has promoted a new manner of singing outside Central Ukraine. It is concluded that the activity of choral groups contributed to the professionalization of the choral performance of Cherkasy region. The activity of spiritual educational centers created the preconditions for the development of musical culture of the Cherkasy region. The prospects for further research, which are to study the activities of professional folk choirs of different regions of Ukraine, have been determined. Keywords: Central Ukraine, Cherkasy region, folk choir, church educational institution, professionalization of amateur singing.

Пиж'янова Н.В., Куценко С.В., Опацький І.Ю.

Уманський державний педагогічний університет імені Павла Тичини

\section{ДОСЛІДЖЕННЯ ВПЛИВУ ЦЕРКОВНИХ НАВЧАЛЬНИХ ЗАКЛАДІВ НА ПРОЦЕС ФОРМУВАННЯ СПЕЦИФІКИ ПІСЕННОГО ВИКОНАННЯ В ЦЕНТРАЛЬНІЙ УКРАЇНІ}

Анотація. У статті розкривається роль церковних осередків у процесі поширення музичної освіти в Центральній Україні. Вказуеться, що у Центральній Україні активізащія процесу формування мережи освітніх закладів на базі церковних установ припадає на другу половину XVI століття. Музична освіта у таких закладах являла собою синтез академічного (світського та церковного) та фольклорного (народного) музикування. Зазначається, що музична освіта другої половини XIX - початку XX століття в Черкаському регіоні мала окремі ознаки професійної освіти. Проаналізована діяльність церковних та церковнопарафріяльних хорових колективів Черкаського регіону. Встановлено, що музична освіта, зокрема, хорове виконавство розповсюджувалось, переважно, через навчальні заклади духовного спрямування, при яких утворювались ансамблі та хорові колективи. Зазначається, що функціонування розгалуженої мережі церковних освітніх осередків сприяла розвитку музичної грамотності серед населення, створила передумови для творчої самореалізації, підвищила загальний культурний рівень. Проаналізована практика функціонування окремих хорових колективів утворених на базі церковних закладів освіти. Зазначається, що взаємодія церковної та світської, народної традицій співу сприяла формуванню нової манери. Вказуеться, що репертуар церковних хорів доповнювався духовними народними піснями, творами календарно-обрядового циклу. Зазначається, що гастрольна діяльність хорових колективів популяризувала нову манеру співу за межами Центральної України. Зроблено висновок, що діяльність хорових колективів сприяла професіоналізації хорового виконавства Черкаського регіону. Діяльність духовних освітніх осередків створила передумови для розвитку музичної культури Черкаського регіону. Визначено перспективи подальших досліджень, які полягають у вивченні діяльності професійних народних хорових колективів різних регіонів України.

Ключові слова: Центральна Україна, Черкаський регіон, народний хор, церковні навчальні заклади, профресіоналізація аматорського співу.

Tntroduction. Beginning in the late Middle Ages, there was a gradual transformation of the nature of the interaction between the church and social institutions. The church and its separate subdivisions (monasteries) become centers of accumulation of existing knowledge and production of the new ones. After some time, it is on the basis of ecclesiastical institutions that educational institutions, which subsequently become secular, emerge.

In Central Ukraine, the process of forming a network of educational institutions on the basis of church institutions was intensified in the second half of the XVI century. Music education was a syn- thesis of academic (secular and ecclesiastical) and folk music in such institutions. As a result, a new tradition of choral singing was formed.

Analysis of recent research and publications. The work [1] is devoted to the study of monasteries as centers of education, including music. The authors analyze the place of music in the process of worship, features of musical practice.

The results of a thorough analysis of the musical art of the Russian Empire, to which Ukraine has been a part of at certain intervals, are highlighted in [2]. The author focuses on the importance of poorly researched centers of art development. 
The creative contribution of Ukrainian artists D. Bortnianskyi and M. Berezovskyi to the development of Eastern European musical culture is explored.

The research of $\mathrm{O}$. Murzina [3] is devoted to the study of the traditions of folk singing style in Central Ukraine. In the article, the author attempts to determine the features of ethnocultural integrity of the territory of the Middle Dnipro region on the basis of folk tradition.

Some issues of choral development were considered by Ukrainian scientists [4; 7].

Problem statement. At the same time, issues related to determining the influence of church educational institutions on the development of music education, the specificity of song performance in Central Ukraine, are not sufficiently explored. Also, it may be scientifically valuable to analyze the practice of functioning of individual choral groups formed on the basis of church educational institutions.

The aim of the article. The purpose of the article is to research the influence of music education of church and parochial educational institutions on the process of forming the specificity of song performance in Central Ukraine.

Results. In the XIX century, the formation of a professional performing type of folk songs in the Cherkasy region was influenced by the existing system of music education. The combination of traditional performance of folk songs and those performing traditions spread through church educational centers formed a special type that influenced the professionalization of folk songs.

In general, music education in the late XIX and early XX centuries in the Cherkasy region had distinctive features of vocational education. The main criteria for vocational training should include:

a) special music education with an extensive knowledge system;

b) the existence of a notographic fixation of the musical text;

c) systematicity and consistency in the transfer of knowledge, skills and abilities through the formation of educational institutions, choral groups with the possibility of translating into a practical educational process;

d) presence of permanent performing (concert) practice;

e) attraction to artistic competence [4].

Music education in the Cherkasy region, in particular, choral performance during the studied period was distributed mainly through educational institutions of the spiritual direction, in which ensembles and choral groups were formed, which had direct performing practice, both during training and after graduation. Scientists from the clergy were trained in singing, had practical experience of singing in the best choirs, and tried to continue the traditions they had learned during their studies and performing in their singing groups.

The leadership of the Kiev religious educational institutions sent to the counties and villages of the province the best graduates who had experience singing in the Metropolitan (Lavra) and Bishops (St. Michael) choirs. Undoubtedly, the choir leaders transmitted the tradition learned during the practice of singing in the above-mentioned groups. The practical aspect of cooperation was also the participation of village choral groups in worship
[5], for example, at the Kiev-Pechersk Lavra and St. Michael's Church.

Among the representatives of the Orthodox clergy of the Cherkasy region there are the following: Overkii Kutkov, Vasilii Karpov, Ananii Kulikovskyi, Yakiv Gordienko, Petr Chevazhevskyi, Georgii Pashuta, Vasilyi Ilnitskyi, Petr Yaschurzhinskyi, Dionysius Andrievskyi, who have had practical experience singing in Lavra and St. Michael's Church choirs.

Educational institutions spread not only the empirical transfer of musical knowledge (singing by ear), but also facilitated the study of musical literacy; some choirs established at the educational institutions not only had regular performing practices, but also performed touring activities within the county or province, that is, in addition to participating in the church service, they also performed the functions of a concert collective. The above-mentioned allows us to define the professionalism of a particular type, that is, its intermediate link, where the highest level has not yet been reached, but the path to the deepening of musical knowledge, improvement of practical skills in the field of performing arts has been started.

In the period under research, according to our calculations, in accordance with archival materials, temples functioned in 394 settlements of the Cherkasy region; also, such information was found [6] that 148 temples functioned in the Uman district. Church-parochial schools were established at each temple.

Each church and parochial school of the Cherkasy region had a choir or ensemble. It should be noted that the activities of some of them were covered in the print media, marked by the highest spiritual leadership (the latter was reflected in church documents).

In music studies we find that most parochial choirs were not large, sometimes they were ensembles. Choir sound can be described as chamber. Completing choral parties was not the main requirement of creating a parochial choir. Male voices are few. The songs were performed with ordinary, simple songs. The singing style is close to folk (in our definition it is "conditionally academic"). In the villages, the main criterion for admission to the church choir was the desire to sing and the minimal musical skills. Usually, the choirs were older women who had extensive experience in church life and were active in parochial life. At the beginning of their existence, such choirs were characterized by a rather open sound, a certain tempo- rhythmic freedom [7].

We found that during the study period, 18 church and ecclesiastical choir groups in the region reached a considerable level of performing skill, touring mainly within their own county or province. For example, the analysis of archival materials [6] testified to the high skill of the church choirs of the church of St. John Theologian v. Sokolivka, The Protection of the Holy Virgin v. Krasnostavki, St. Demetrius v. Nesterivka, The Protection of the Holy Virgin v. Babanka and the Temple of St. Dmitry v. Svynarky. At the beginning of the XX century, the high professional skill of choral groups of the Uman district was noted by the leadership of the Holy Synod. These are, in particular, such groups as the choir of the parochial school 
at the Trinity Church in Uman [6, p. 51], the local choir of the Legedzyn Church of St. Paraskeva [6, p. 53], Ivanky Choir, Choirs of Church and Parochial Schools of Kuzmina Greblya, Perehonovska and Rohivska Church and Parochial Schools [6, p. 53], choir of Hizhnya village [6, p. 329] and others.

The choir from the town of Ivanky was honored with a performance at the Mykhailivskyi Monastery and received the blessing of the first vicar of the Kyiv Diocese of the Most Holy Nicodemus [5]. The touring activity of the collective, holding concerts before the highest spiritual leadership, presentation of their mastery in Kyiv demonstrated the high level of performing skill of the choral collective of the Ivanky Church and Parochial School. Undoubtedly, the activity of the team contributed to the development and professionalization of the region's choral performance.

The activity of some choirs goes beyond church music and begins the practice of concert performance [8]. In some cases, the concert activity of the church choirs was of such great interest to the public that the collective subordinated to the artistic tastes of the listeners. As a result, there was a transformation of the repertoire - a decrease in spiritual music and an increase in works of secular music and folk songs. The highest quality of performing spiritual music by the choir of the Church of the Assumption of the Blessed Virgin Mary in the village Okhmativ became the reason for the popularity of this band and thus contributed to the concert stage and the first steps in the touring activity. Such expansion of the functions of the choir - from the church-parochial to the concert itself - required a certain expansion of the repertoire, which already included spiritual music, secular works and folk song. Confirmation of this view is also found in V. Mudryk's scientific research: "During the leisure and holidays in the courtyard of the temple, church choirs often performed folk works of the calendar-ritual cycle (in particular, carols, bounties)" [7]. Thus, in the repertoire of church choirs, spiritual folk songs, works of the calendar-ritual cycle and, in fact, a folk song, also got their place.

The activity of the spiritual educational centers created the preconditions for the development of the musical culture of the Cherkasy region, since a large part of the choirs were not limited to participation in worship but also functioned outside the temple. In view of the above, it should be noted that such groups consisted of singers who had professional practical experience and singing style of "cultivated", close to the academic and uneducated singers who only knew the performing style, which they learned well from childhood folk (ethnocharacteristic of the locality). The most striking representative of such a combination can also be called the Okhmatov Choir, which included trained and folk singers.

So, the activity of the network of spiritual educational centers promotes the development of musical literacy, constant practice of singing, indirect learning of professional composer's directions, forms and techniques. Church choirs of the second half of the XIX - early XX centuries (a contingent of which was raised in church-parochial schools and spiritual schools) act as educational centers for singers, providing them with performing practice, an opportunity to improve their creative potential.

Conclusions. The catalysts for the development of music education, including choral performance, in Central Ukraine were mainly church centers. Research into the development of music education in Central Ukraine has allowed us to determine the directions of its distribution, to evaluate the impact on the formation and activities of choral groups.

Elementary musical literacy and church singing skills acquired in church-parochial schools, combined with the tradition of singing folk songs in Central Ukraine, have formed a synthetic type. Its distinctive feature is the combination of two different traditions. The stability of the God's Mass at the churches took the singers' skill to a new, better and more professional level. Under the guidance of the learned thanksgiving, the performance became more secular. The popularity of individual church and church-parochial choirs contributed to the expansion of the repertoire, the launch of concert activities outside the temple. Tours of choirs from the Cherkasy region popularized the singing style outside Central Ukraine.

Prospects for further research are to study the activities of professional folk choirs of different regions of Ukraine.

\section{References:}

1. Ferzoco G. (2000). Medieval Monastic Education. London snd New York : Leicester University Press.

2. RitzarevM.(2006). Eighteenth-CenturyRussianMusic.London:Routledge.doi:https://doi.org/10.4324/9781315094601

3. Murzina O. (2014). Serednia Naddniprianshchyna $v$ istorychnomu konteksti formuvannia tradytsii problemy etnomuzykolohii [Middle Dnipro region in the historical context of the formation of the tradition]. Problem of ethnomusicology, no. 9, pp. 12-38. (in Ukrainian)

4. Bondar E. (2013). Henezys profesiinoho khorovoho vykonavstva vid vytokiv do XVIII stolittia [The Genesis of Professional Choral Performance: From Origins to the seventeenth century]. Composer creativity and musical performance. Scientific Bulletin of Tchaikovsky, no. 107, pp. 104-115. (in Ukrainian)

5. Palomnicheskaja jekskursija cerkovnogo hora m. Ivanek Umanskogo uezda [Pilgrimage excursion to the church choir in Ivanky district of the Uman district] (1912). Kiev diocesant sheets, no. 27. (in old Russian)

6. Kuznets T. (2006). Pravoslavne dukhovenstvo Umanshchyny XIX - pochatku XX stolittia [The Orthodox clergy of the Uman region of the XIX - early XX centuries]. Kyiv : Publishing and Printing Center "Kyiv University". (in Ukrainian).

7. Mudryk V. (2011). Narodnist tserkovnoparafiialnoi shkoly v Ukraini XVIII - XIX stolit [Nationality of the ChurchParochial School in Ukraine of the XVIII - XIX Centuries]. Topical Problems of the History, Theory and Practice of Art Culture, no. 26, pp. 169-177. (in Ukrainian)

8. Pyzhianova N. (2016). Okremi aspekty dukhovnoi muzyky Porfyriia Demutskoho [Selected Aspects of Porphyryi of Demutskyi's Spiritual Music]. The Ethnology Notebooks, no. 1, pp. 195-200. (in Ukrainian) 